Supporting information

Light driven water oxidation with the Ir-blue catalyst and the $\mathrm{Ru}(\mathrm{bpy})_{3}{ }^{2+} / \mathrm{S}_{2} \mathrm{O}_{8}{ }^{2-}$ cycle: photogeneration of active dimers, electron transfer kinetics, and light synchronization for oxygen evolution with high quantum efficiency.

$$
\text { Andrea Volpe, }{ }^{a} \text { Cristina Tubaro, }{ }^{a} \text { Mirco Natali, }{ }^{*}, b \text { Andrea Sartorel, },{ }^{*},
$$

Gary W. Brudvig ${ }^{c}$ and Marcella Bonchio ${ }^{a}$

${ }^{a}$ Department of Chemical Sciences, University of Padova, via Marzolo 1, 35131 Padova, Italy.

${ }^{b}$ Department of Chemical and Pharmaceutical Sciences, University of Ferrara, and Centro

Interuniversitario per la Conversione Chimica dell'Energia Solare (SolarChem), sez. di Ferrara, Via

L. Borsari 46, 44121 Ferrara, Italy.

${ }^{c}$ Yale Department of Chemistry, University of Yale, 225 Prospect St, New Haven, CT 06511-8499.

Synthesis $\quad$ S1

Photogeneration of Ir-blue $\quad$ S2

Laser flash photolysis $\quad$ S2

$\begin{array}{ll}\text { Water oxidation experiments } & \text { S2 }\end{array}$

Irradiation sources $\quad$ S3

Kinetic model used for the determination of the bimolecular rate constants for the S4

hole transfer from $\operatorname{Ru}(\mathrm{III})$ to $\operatorname{Ir}(\mathrm{IV})$ intermediates $\left(\boldsymbol{k}_{\text {I-average }}\right)$ and Ir-blue $\left(\boldsymbol{k}_{\text {Ir-blue }}\right)$

Schemes and figures $\quad$ S9

$\begin{array}{lr}\text { References } & \text { S24 }\end{array}$ 
Synthesis. Synthesis of pyalc ligand: ${ }^{1} 1.94 \mathrm{~g}$ (16 mmol) of 2-acetylpyridine were dissolved in 30 $\mathrm{mL}$ of anhydrous diethyl ether and cooled with an ice bath; $20 \mathrm{~mL}$ of $1 \mathrm{M}$ solution of $\mathrm{CH}_{3} \mathrm{MgBr}$ in diethyl ether were then added dropwise; the mixture was stirred for 2 hours, and then treated with $\mathrm{HCl} 37 \%$, observing the formation of two layers. The aqueous layer was separated and extracted with diethyl ether. The organic fractions were finally washed with water, dried over $\mathrm{MgSO}_{4}$ before evaporating the solvent. The product was purified over flash chromatography (hexane : ethyl acetate 3:1 as the eluent), with a final $50 \%$ yield. Characterizations were in agreement with literature.

Synthesis of $\left[\operatorname{Ir}_{2}(\mu-\mathrm{OH})_{3} \mathrm{Cp}^{*}{ }_{2}\right] \mathrm{OH}: 250 \mathrm{mg}(0.31 \mathrm{mmol})$ of $\left[\mathrm{Ir}_{2}(\mu-\mathrm{Cl})_{2} \mathrm{Cp}^{*}{ }_{2}\right] \mathrm{Cl}_{2}$ were suspended in $10 \mathrm{~mL}$ of water, in the presence of $176 \mathrm{mg}(0.76 \mathrm{mmol})$ of $\mathrm{Ag}_{2} \mathrm{O}$. The suspension was vigorously stirred for 4 hours, then it was filtered over celite, and the $\left[\operatorname{Ir}_{2}(\mu-\mathrm{OH})_{3} \mathrm{Cp}^{*}{ }_{2}\right] \mathrm{OH}$ product was recovered in $60 \%$ yield by evaporation of water.

Synthesis of $1:^{2} 22 \mathrm{mg}(0.16 \mathrm{mmol})$ of pyalc ligand were added to $4 \mathrm{~mL}$ of an aqueous solution containing $58 \mathrm{mg}(0.08 \mathrm{mmol})$ of $\left[\mathrm{Ir}_{2}(\mu-\mathrm{OH})_{3} \mathrm{Cp}^{*}{ }_{2}\right] \mathrm{OH}$ and stirred overnight at room temperature. Evaporation of the solvent yielded $\operatorname{Ir}\left(\mathrm{Cp}^{*}\right)($ pyalc)OH, whose identity was confirmed by ESI-MS $\mathrm{m} / \mathrm{z}=462-464$, attributed to the $\left[\operatorname{Ir}\left(\mathrm{Cp}^{*}\right)(\text { pyalc })\right]^{+}$ion, see spectrum and isotopic pattern simulation below.
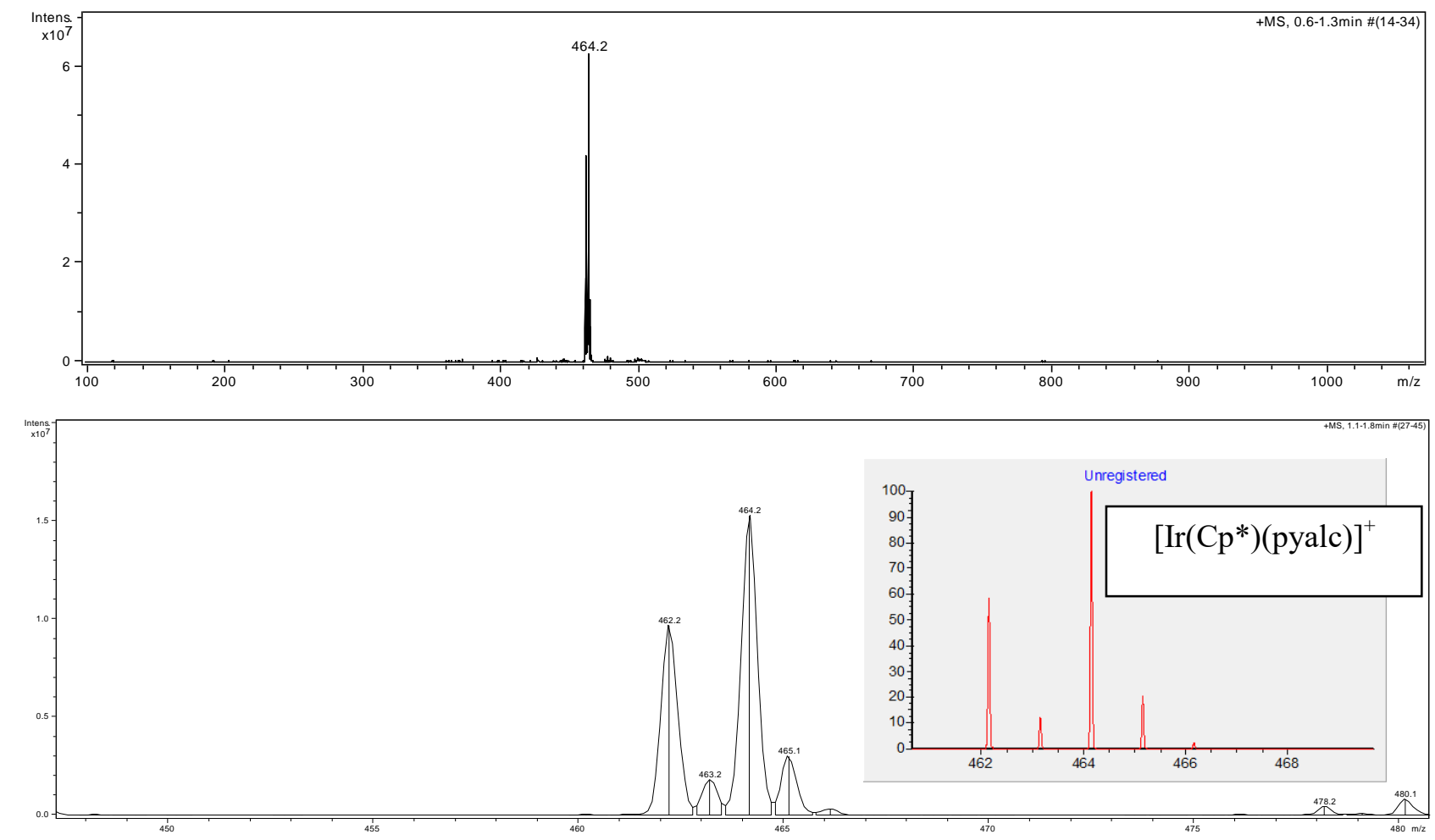

Experimental ESI-MS(+) of $\operatorname{Ir}\left(\mathrm{Cp}^{*}\right)$ (pyalc)OH $\left(10^{-5} \mathrm{M}\right.$ in water) registered with MSD SL Trap mass spectrometer with ESI source (Agilent Technologies), and simulated isotopic pattern of the $\left[\operatorname{Ir}\left(\mathrm{Cp}^{*}\right)(\text { pyalc })\right]^{+}$ion. 
Photogeneration of Ir-blue. Experiments were performed by irradiating a cuvette containing the Ir precursor 1, $\mathrm{Ru}\left(\right.$ bpy) ${ }_{3}{ }^{2+}$ and $\mathrm{Na}_{2} \mathrm{~S}_{2} \mathrm{O}_{8}{ }^{2-}$ in $50 \mathrm{mM} \mathrm{Na}_{2} \mathrm{SiF}_{6} / \mathrm{NaHCO}_{3}$ buffer, pH 5.2. Irradiation was performed with a white LED lamp positioned at $20 \mathrm{~cm}$ from the cuvette $\left(3.8 \mathrm{~mW} / \mathrm{cm}^{2}\right)$. Two conditions were investigated:

(a) $\mathrm{Ru}$ (bpy) ${ }_{3}^{2+} 1 \mathrm{mM}$, and $\mathrm{Na}_{2} \mathrm{~S}_{2} \mathrm{O}_{8}{ }^{2-} 5 \mathrm{mM}, 150-400 \mu \mathrm{M}$ (conditions that were then adopted in light driven water oxidation experiments), with a $1 \mathrm{~mm}$ optical path cuvette (experiments reported in Figure 1);

(b) $\mathrm{Ru}$ (bpy) ${ }_{3}^{2+} 50 \mu \mathrm{M}$, and $\mathrm{Na}_{2} \mathrm{~S}_{2} \mathrm{O}_{8}{ }^{2-} 5 \mathrm{mM}, 1250-500 \mu \mathrm{M}$ (conditions that were then adopted in flash photolysis experiments), with a $1 \mathrm{~cm}$ optical path cuvette (experiments reported in Figure S8).

Laser flash photolysis. Nanosecond transient absorption measurements were performed with a custom laser spectrometer comprised of a Continuum Surelite II Nd:YAG laser (FWHM $6-8$ ns) with a frequency doubled $(532 \mathrm{~nm})$ or triple $(355 \mathrm{~nm})$ options, an Applied Photo-physics xenon light source including a mod. $720150 \mathrm{~W}$ lamp housing, a mod. 620 power-controlled lamp supply and a mod. 03-102 arc lamp pulser. Laser excitation was provided at $90^{\circ}$ with respect to the white light probe beam. Light transmitted by the sample was focused onto the entrance slit of a $300 \mathrm{~mm}$ focal length Acton SpectraPro 2300i triple grating, flat field, double exit monochromator equipped with a photomultiplier detector (Hamamatsu R3896) and a Princeton Instruments PIMAX II gated intensified CCD camera, using an RB Gen II intensifier, an ST133 controller and a PTG pulser. Signals from the photomultiplier (Hamamatsu R928) were processed by means of a Teledyne LeCroy 604Zi digital oscilloscope (400 MHz, $20 \mathrm{GS} / \mathrm{s}$ ).

Water oxidation experiments. In a typical experiment, $15 \mathrm{~mL}$ of $50 \mathrm{mM} \mathrm{NaHCO} 3 \mathrm{Na}_{2} \mathrm{SiF}_{6}$ aqueous buffer ( $\mathrm{pH}$ 5.2) containing $\left[\mathrm{Ru}(\text { bpy })_{3}\right] \mathrm{Cl}_{2} \cdot 6 \mathrm{H}_{2} \mathrm{O}(1 \mathrm{mM}), \mathrm{Na}_{2} \mathrm{~S}_{2} \mathrm{O}_{8}(5 \mathrm{mM})$ and the precatalyst $1(50 \mu \mathrm{M})$ were introduced into a home-made cylindrical glass reactor (internal diameter $18 \mathrm{~mm}$, total internal volume of $24 \mathrm{~mL}$ ), deoxygenated with nitrogen for about 20 minutes and allowed to equilibrate at $25{ }^{\circ} \mathrm{C}$ under the exclusion of light. The solution was then irradiated with a white LED lamp positioned at $20 \mathrm{~cm}$ from the reactor $\left(3.8 \mathrm{~mW} / \mathrm{cm}^{2}\right)$ or with a series of six monochromatic LEDs emitting at $450 \mathrm{~nm}$ and with FWHM = $10 \mathrm{~nm}$ (LED450-06 from Roithner Lasertechnik $\mathrm{GmbH}$; photon flux was modulated in the range $4.42 \times 10^{-9}$ to $2.12 \times 10^{-7}$ einstein $\cdot \mathrm{s}^{-1}$; the irradiation power of the LEDs was measured with an AvaSpec-2048 Fiber Optic Spectrometer from Avantes.). Oxygen evolution was monitored with a FOXY-R-AF probe inserted into the reaction headspace and interfaced with Neofox Real-Time software for data collection.

In the case of the experiment employing isotopically enriched water, a home-made schlenk type reactor (total volume of $7.2 \mathrm{ml}$ ), and employing $2 \mathrm{ml}$ of solution, by irradiating with a white LED 
lamp positioned at $20 \mathrm{~cm}$ from the reactor $\left(3.8 \mathrm{~mW} / \mathrm{cm}^{2}\right)$. Gas chromatography coupled to mass spectrometry analysis was conducted with an Agilent Technologies 7890A GC system coupled to a 5975C mass spectrometer with triple-axis detector, equipped with a HP-PLOTQ (30 m length, $0.320 \mathrm{~mm}$ OD, $20 \mu \mathrm{m}$ film thickness) and a HP-MOLSIEVE (30 m length, $0.320 \mathrm{~mm}$ OD, $12 \mu \mathrm{m}$ film thickness) columns, put in series.

\section{Irradiation sources}

White LED lamp emission $\left(3.8 \mathrm{~mW} / \mathrm{cm}^{2}\right.$ at $20 \mathrm{~cm}$ distance $)$

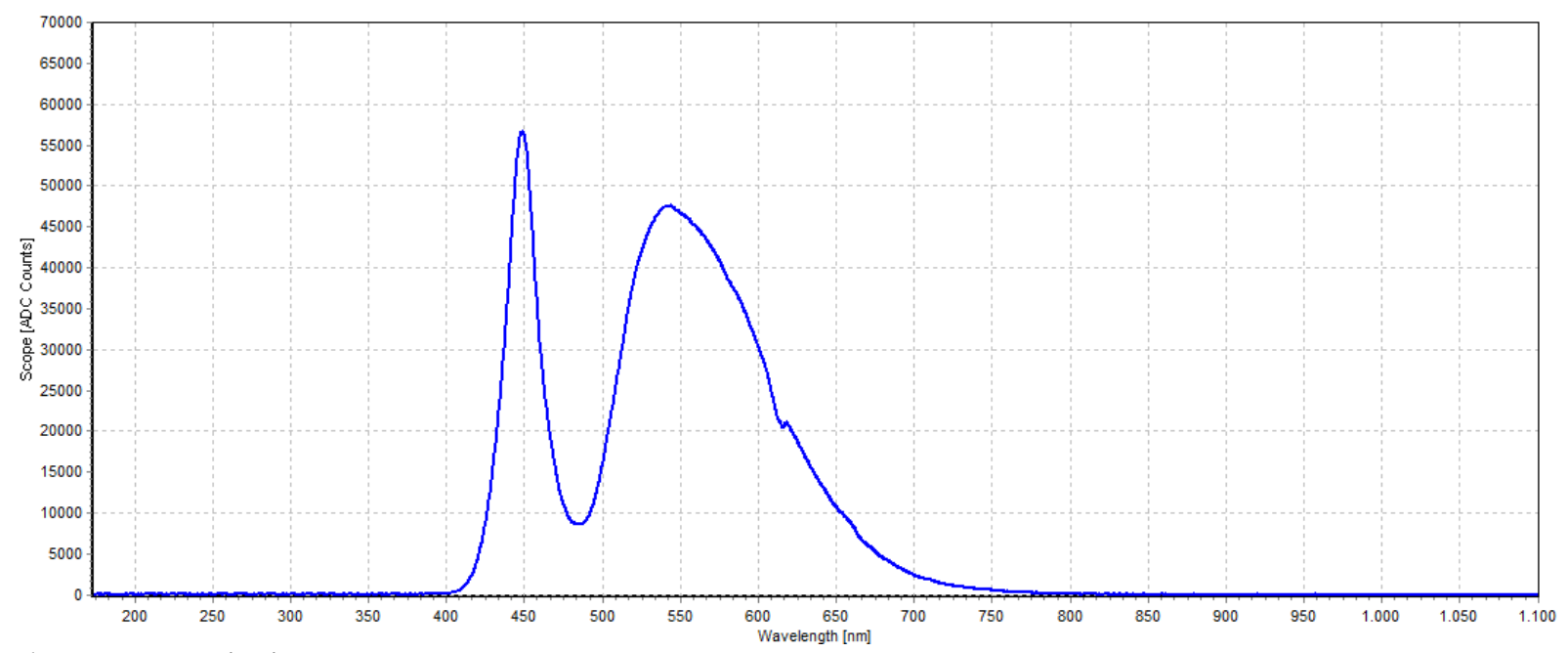

Blue LED emission

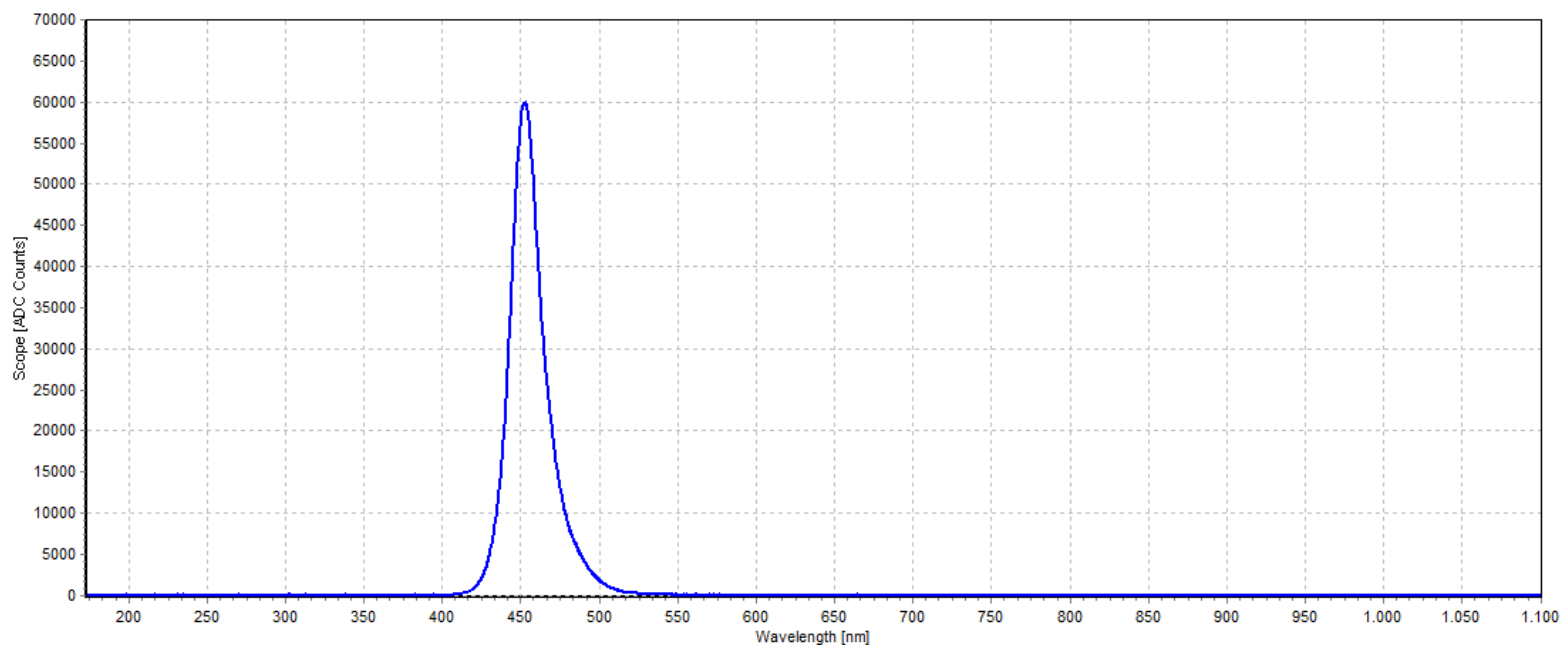


Kinetic model used for the determination of the bimolecular rate constants for the hole transfer from $\operatorname{Ru}(\mathrm{III})$ to $\operatorname{Ir}(\mathrm{IV})$ intermediates $\left(\boldsymbol{k}_{\text {I-average }}\right)$ and Ir-blue $\left(\boldsymbol{k}_{\text {Ir-blue }}\right)$

Laser flash photolysis of solutions containing $50 \mathrm{mM}\left[\mathrm{Ru}(\mathrm{bpy})_{3}\right] \mathrm{Cl}_{2} \cdot 6 \mathrm{H}_{2} \mathrm{O}, 5 \mathrm{mM} \mathrm{Na} \mathrm{S}_{2} \mathrm{O}_{8}, 50 \mathrm{mM}$ $\mathrm{Na}_{2} \mathrm{SiF}_{6} / \mathrm{NaHCO}_{3}$ buffer $\mathrm{pH}$ 5.2, and 0.25-0.50 mM Ir(III) monomeric complex have been performed at different time delays along the continuous irradiation of the solutions with white light, allowing for the accumulation of Ir-blue as observed from the absorption spectra.

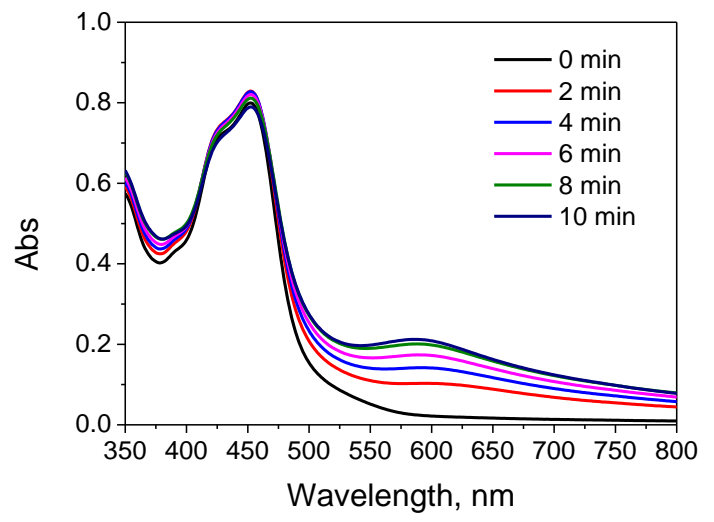

$[\mathbf{1}]_{0}=0.25 \mathrm{mM}$

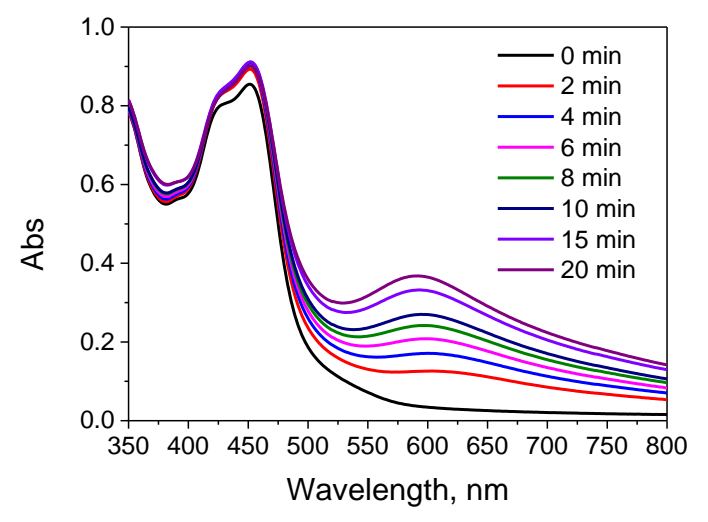

$[1]_{0}=0.50 \mathrm{mM}$

The pseudo-first order rate constant $k_{\mathrm{obs}}$ has been measured at each time delay by fitting the respective kinetic trace using a single-exponential function.
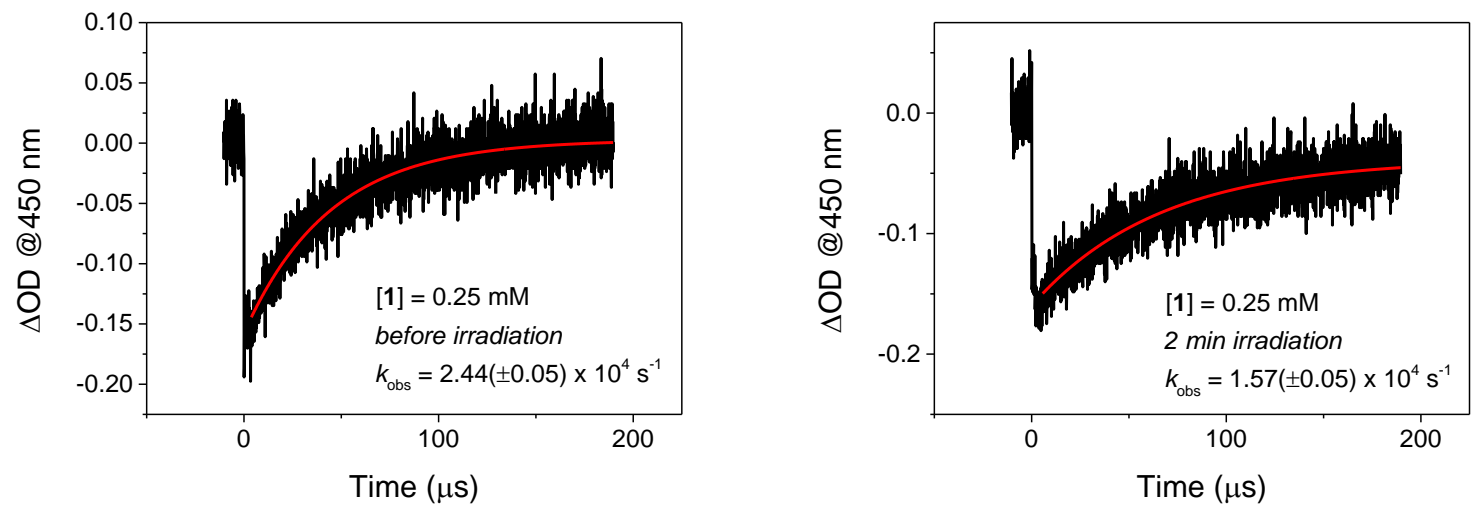

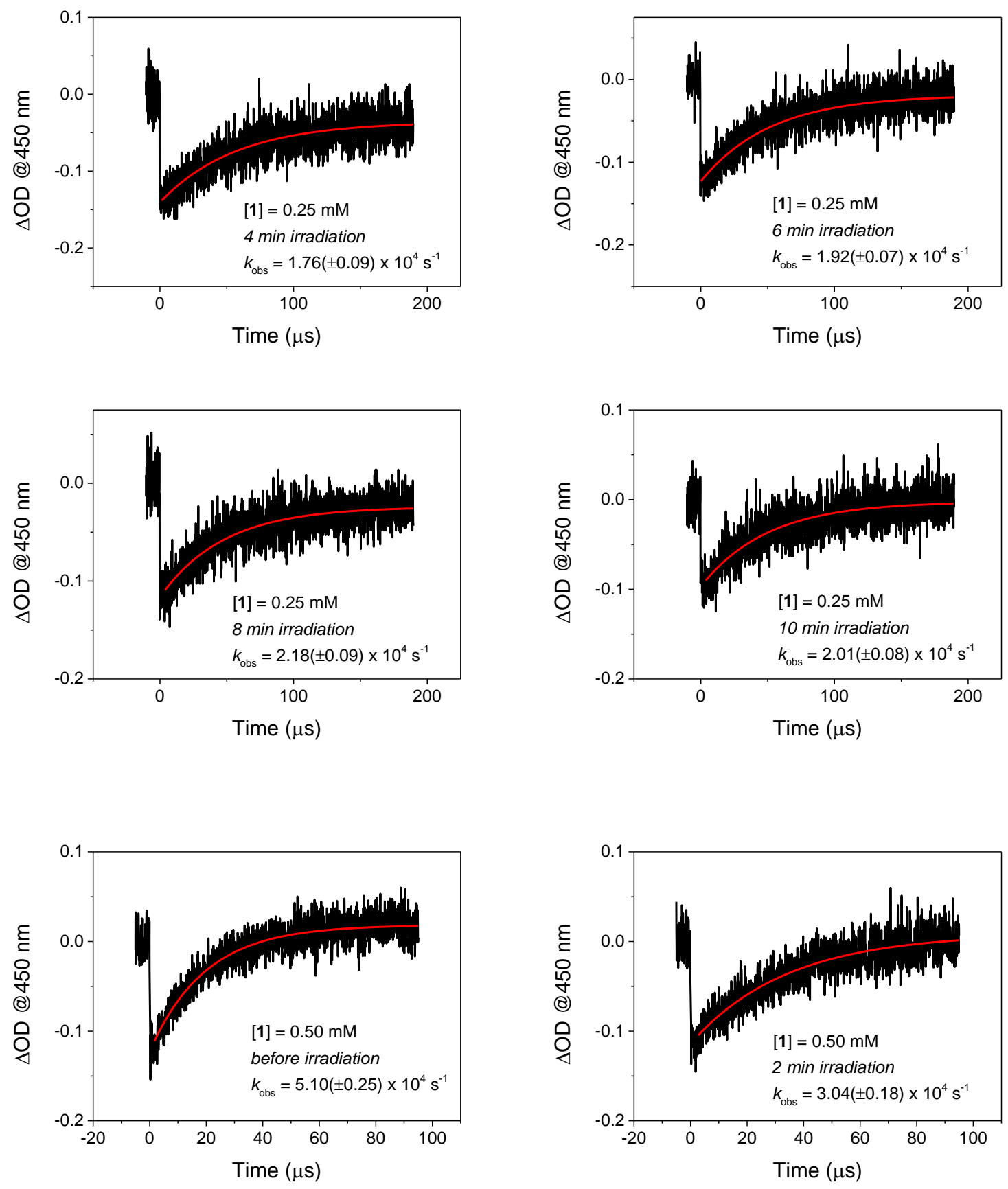

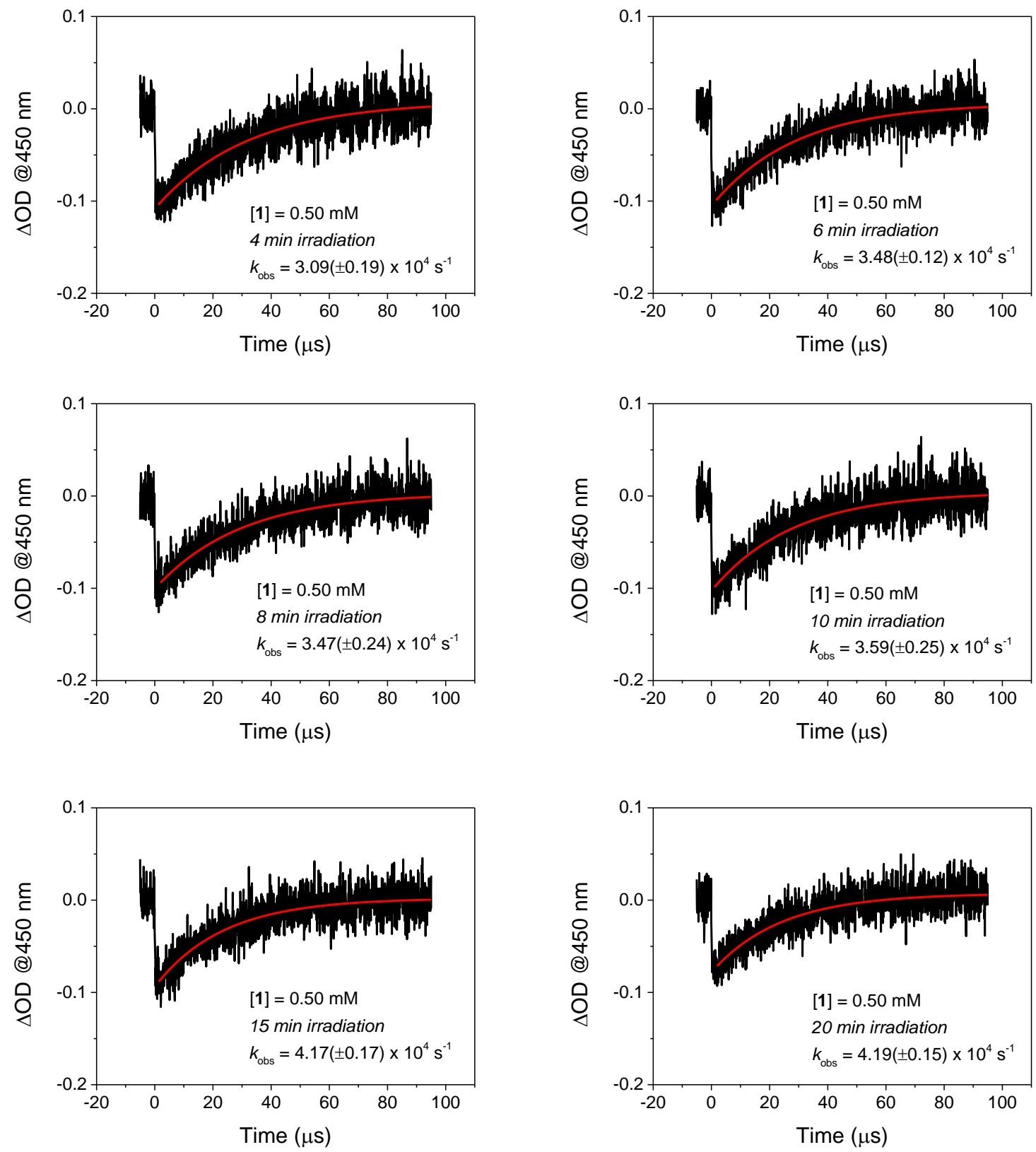

The $k_{\mathrm{obs}}$ value changes as a function of the amount of Ir-blue formed (the latter estimated using the absorbance value at $588 \mathrm{~nm}$ and a molar extinction coefficient of $3200 \mathrm{M}^{-1} \mathrm{~cm}^{-1}$, see Figure S4). 


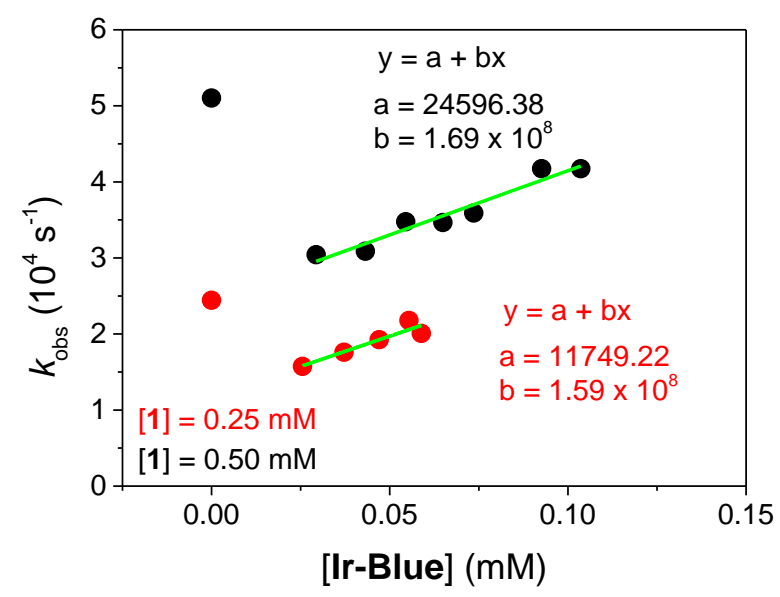

The dependence of the $k_{\mathrm{obs}}$ vs. [Ir-blue] has been treated according to eq S1, S2 (eq 10, 11 of the main text) and eq S3.

$$
\begin{aligned}
& k_{\text {obs }}=k_{1} \times[\mathbf{1}]+\sum k_{\mathrm{Ii}} \times\left[\mathbf{I}_{\mathbf{i}}\right]+k_{\text {Ir-blue }} \times[\mathbf{I r} \text {-blue }] \\
& k_{\text {I-average }}=\sum k_{I i} \times\left[\mathbf{I}_{\mathbf{i}}\right] / \sum\left[\mathbf{I}_{\mathbf{i}}\right] \\
& k_{\text {obs }}=k_{1} \times[\mathbf{1}]+k_{\text {I-average }} \times\left(\sum\left[\mathbf{I}_{\mathbf{i}}\right]\right)+k_{\text {Ir-blue }} \times[\text { Ir-blue }]
\end{aligned}
$$

When the concentration of [Ir-blue] is $>>0.025 \mathrm{mM}$, we can assume that pristine $\mathbf{1}$ is practically disappeared, so that eq S3 can be approximated to eq S4.

$$
\mathrm{k}_{\text {obs }} \approx k_{\text {I-average }} \times\left(\Sigma\left[\mathbf{I}_{\mathbf{i}}\right]\right)+\mathrm{k}_{\text {Ir-blue }} \times[\mathbf{I r} \text {-blue }]
$$

Considering that $[\mathbf{1}]_{0}=\left(\Sigma\left[\mathbf{I}_{\mathbf{i}}\right]\right)+2 \times[\mathbf{I r}$-blue $]$, according to the mass balance for the iridium species, eq S4 can be rearranged into eq S5.

$$
\mathrm{k}_{\text {obs }}=k_{\text {I-average }} \times[1]_{0}+\left(\mathrm{k}_{\text {Ir-blue }}-2 k_{\text {I-average }}\right) \times[\text { Ir-blue }]
$$

Fitting of the two datasets in the range [Ir-blue] $>0.05 \mathrm{mM}$ (green traces above) provides a linear correlation according to eq S5. From the intercepts, we can estimate $k_{\text {I-average }}=4.9 \times 10^{7}$ and $4.7 \times 10^{7}$ $\mathrm{M}^{-1} \mathrm{~s}^{-1}$ at $[1]_{0}=0.50$ and $0.25 \mathrm{mM}$, respectively, and from the slopes we can then obtain $\mathrm{k}_{\text {Ir-blue }}=$ $2.7 \times 10^{8}$ and $2.6 \times 10^{8} \mathrm{M}^{-1} \mathrm{~s}^{-1}$ at $[1]_{0}=0.50$ and $0.25 \mathrm{mM}$, respectively. The rate constants $k_{\mathrm{I} \text {-average }}=$ $(4.8 \pm 0.1) \times 10^{7} \mathrm{M}^{-1} \mathrm{~s}^{-1}$ and $\mathrm{k}_{\text {Ir-blue }}=(2.65 \pm 0.05) \times 10^{8} \mathrm{M}^{-1} \mathrm{~s}^{-1}$ have been then used for the interpolation 
of the experimental kinetic data according to eq S3. Within this treatment, the complete disappearance of pristine $\mathbf{1}$ has been assumed at [Ir-blue] $>0.02 \mathrm{mM}$.

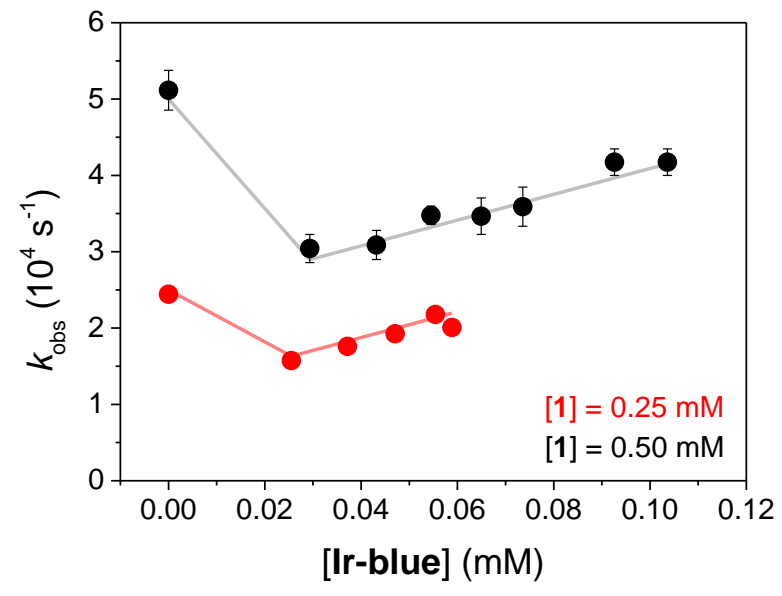

The same plot is reported in the main text using the Ir-Blue formation yield in the X-axis. 


$$
\begin{aligned}
& \mathrm{Ru}(\mathrm{bpy})_{3}{ }^{2+}+\mathrm{h} v \stackrel{\text { (step 1) }}{\longrightarrow} * \mathrm{Ru}(\mathrm{bpy})_{3}{ }^{2+} \\
& { }^{*} \mathrm{Ru}(\mathrm{bpy})_{3}{ }^{2+}+\mathrm{S}_{2} \mathrm{O}_{8}{ }^{2-} \stackrel{(\text { step } 2)}{\longrightarrow} \mathrm{Ru}(\mathrm{bpy})_{3}{ }^{3+}+\mathrm{SO}_{4}{ }^{--}+\mathrm{SO}_{4}{ }^{2-} \\
& \mathrm{Ru}(\mathrm{bpy})_{3}{ }^{2+}+\mathrm{SO}_{4} \cdot \stackrel{(\text { step 3) }}{\longrightarrow} \mathrm{Ru}(\mathrm{bpy})_{3}{ }^{3+}+\mathrm{SO}_{4}{ }^{2-} \\
& \mathrm{Ru}(\mathrm{bpy})_{3}{ }^{3+}+\mathbf{1} \stackrel{\text { (step 4) }}{\longrightarrow} \mathrm{Ru}(\mathrm{bpy})_{3}{ }^{2+}+\mathrm{I}_{\mathbf{1}} \\
& (\mathrm{n}-1) \operatorname{Ru}(\mathrm{bpy})_{3}{ }^{3+}+\mathrm{I}_{\mathbf{1}} \stackrel{\text { (step 5) }}{\longrightarrow}(\mathrm{n}-1) \mathrm{Ru}(\mathrm{bpy})_{3}{ }^{2+}+\mathbf{I}_{\mathbf{n}} \\
& \mathrm{Ru}(\mathrm{bpy})_{3}{ }^{3+}+\mathrm{I}_{\mathbf{n}} \stackrel{(\text { step 6)}}{\longrightarrow} \mathrm{Ru}(\mathrm{bpy})_{3}{ }^{2+}+\text { Ir-blue } \\
& 4 \mathrm{Ru}(\mathrm{bpy})_{3}{ }^{3+}+\text { Ir-blue } \stackrel{\text { (step 7) }}{\longrightarrow} 4 \mathrm{Ru}(\mathrm{bpy})_{3}{ }^{2+}+\text { Ir-blue (ox) } \\
& \text { Ir-blue }{ }^{(\mathrm{OX})}+2 \mathrm{H}_{2} \mathrm{O} \stackrel{\text { (step 8) }}{\longrightarrow} \text { Ir-blue }+\mathrm{O}_{2}+4 \mathrm{H}^{+}
\end{aligned}
$$

Scheme S1. Photocatalytic $\mathrm{Ru}(\mathrm{bpy})_{3}{ }^{2+} / \mathrm{S}_{2} \mathrm{O}_{8}{ }^{2-}$ cycle, leading to activation of $\mathbf{1}$ into Ir-blue, and water oxidation catalysis by Ir-blue. Photogeneration of the $\mathrm{Ru}(\mathrm{bpy})_{3}{ }^{3+}$ oxidant occurs by light absorption by the $\mathrm{Ru}(\mathrm{bpy})_{3}{ }^{2+}\left(\lambda_{\max }=450 \mathrm{~nm}, \varepsilon=1.4 \times 10^{4} \mathrm{M}^{-1} \mathrm{~cm}^{-1}\right)$ and generation of a triplet excited state ${ }^{*} \mathrm{Ru}(\mathrm{bpy})_{3}{ }^{2+}$ (step 1) which activates a series of electron transfer events: reaction of $* \mathrm{Ru}\left(\right.$ bpy) ${ }_{3}{ }^{2+}$ with $\mathrm{S}_{2} \mathrm{O}_{8}{ }^{2-}$ (oxidative quenching of the photosensitizer, step 2) and generation of $\mathrm{Ru}(\mathrm{bpy}) 3^{3+}$ and of a sulfate radical anion; formation of a second equivalent of Ru(bpy) $3^{3+}$ by the reaction of the sulfate radical with $\mathrm{Ru}(\mathrm{bpy})_{3}{ }^{2+}$, step 3 .

(a) Considering only oxidation of $\operatorname{Ir}(\mathrm{III})$ to $\operatorname{Ir}(\mathrm{IV}) ; \mathrm{Cp}^{*}=\mathrm{C}_{10} \mathrm{H}_{15}{ }^{-} ; \mathrm{L}$ apical ligands (not involved in redox)

$2 \mathrm{Ir}^{\mathrm{III}}($ pyalc $)\left(\mathrm{Cp}^{*}\right) \mathrm{OH}+\mathbf{2} \mathbf{R u}^{\mathrm{III}}+6 \mathrm{~L} \rightarrow($ pyalc $) \mathrm{Ir}^{\mathrm{IV}}(\mathrm{OH}) \mathrm{Ir}^{\mathrm{IV}}($ pyalc $) \mathrm{L}_{6}+2 \mathrm{Ru}^{\mathrm{II}}+2 \mathrm{Cp}^{*}+\mathrm{OH}^{-}$

(b) Considering full oxidation of $\mathrm{Cp}^{*}$ to $\mathrm{CH}_{3} \mathrm{COOH}$

$2 \mathrm{Cp}^{*}+32 \mathbf{R u}^{\text {III }}+20 \mathrm{H}_{2} \mathrm{O} \rightarrow 10 \mathrm{CH}_{3} \mathrm{COOH}+32 \mathrm{Ru}^{\mathrm{II}}+30 \mathrm{H}^{+}$

(c) TOTAL (sum of a and b):

$2 \mathrm{Ir}^{\mathrm{III}}$ (pyalc) $\left(\mathrm{Cp}^{*}\right) \mathrm{OH}+\mathbf{3 4} \mathbf{R u}^{\mathrm{III}}+6 \mathrm{~L}+19 \mathrm{H}_{2} \mathrm{O} \rightarrow$

$\rightarrow($ pyalc $) \operatorname{Ir}^{\mathrm{IV}}(\mathrm{OH}) \mathrm{Ir}^{\mathrm{IV}}($ pyalc $) \mathrm{L}_{6}+34 \mathrm{Ru}^{\mathrm{II}}+10 \mathrm{CH}_{3} \mathrm{COOH}+29 \mathrm{H}^{+}$

Scheme S2. Expected $\mathrm{Ru} / \mathrm{Ir}$ stoichiometry for the conversion of $\mathbf{1}$ into Ir-blue. An $\operatorname{Ir}($ pyalc $)\left(\mathrm{Cp}^{*}\right)(\mathrm{OH})$ precursor $(\mathbf{1})$ is expected to react with $1-17$ equivalents of $\mathrm{Ru}(\mathrm{III})$, depending on the level of oxidation of Cp*; formation of the Ir-blue should require 2-34 eq. of Ru(III). 


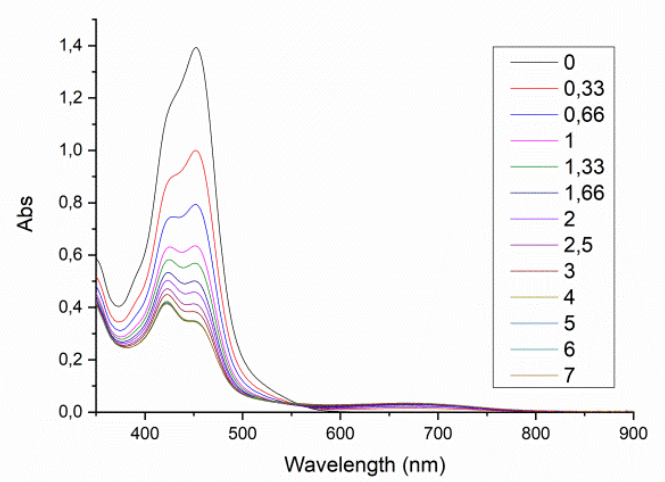

Figure S1. Absorption spectra of a solution containing $1 \mathrm{mM} \mathrm{Ru}(\mathrm{bpy})_{3}{ }^{2+}, 5 \mathrm{mM} \mathrm{Na}_{2} \mathrm{~S}_{2} \mathrm{O}_{8}$ (blank) in $50 \mathrm{mM} \mathrm{Na} 2 \mathrm{SiF}_{6} / \mathrm{NaHCO}_{3}$ buffer $(\mathrm{pH}=5.2)$ at different times $(0-7 \mathrm{~min})$ upon illumination with white light (white LED, $3.8 \mathrm{mWcm}^{-2}$, optical path of the cuvette $=1 \mathrm{~mm}$ ). 

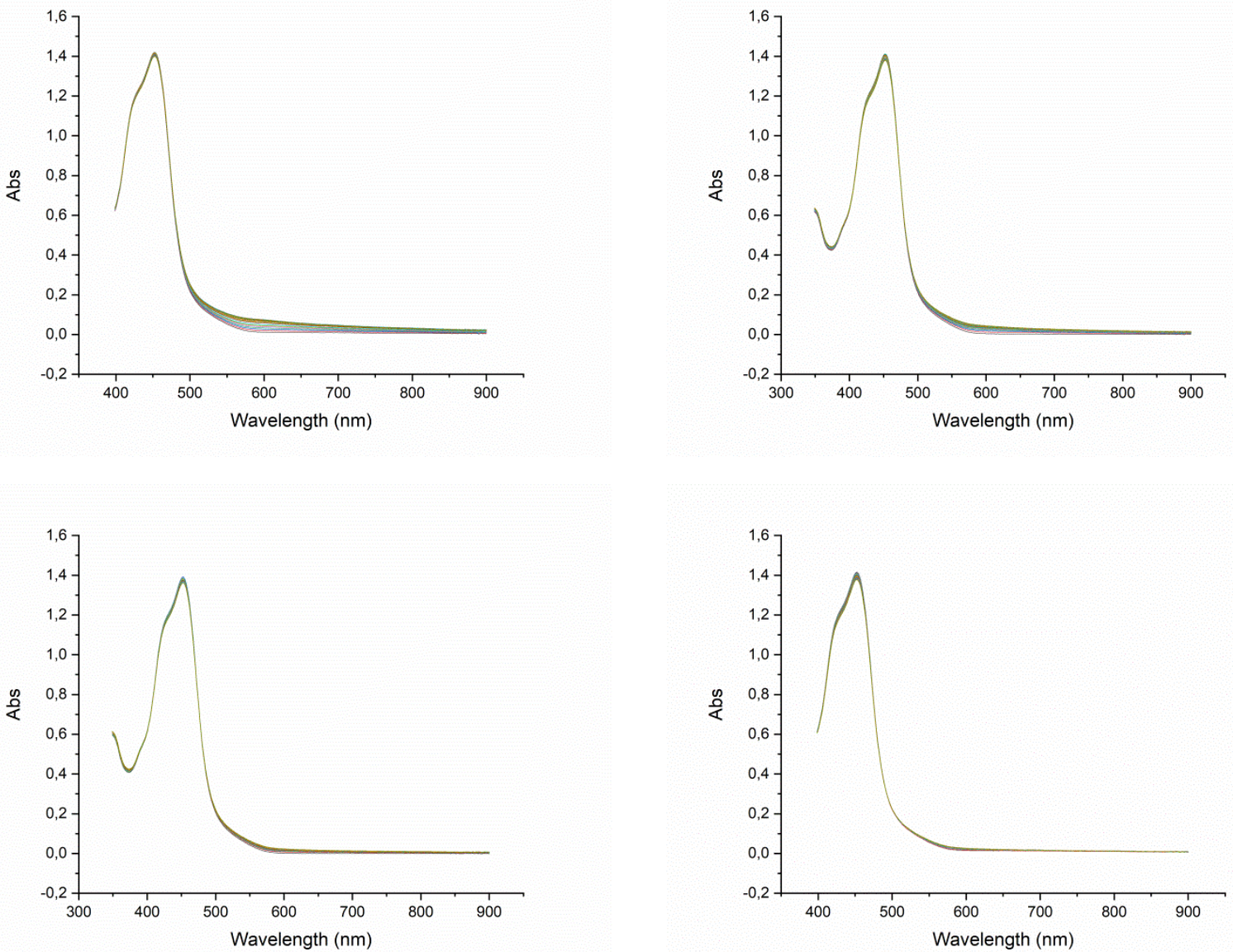

Figure S2. Absorption spectra of solutions containing $1 \mathrm{mM} \mathrm{Ru}(\mathrm{bpy})_{3}{ }^{2+}, 5 \mathrm{mM} \mathrm{Na} \mathrm{S}_{2} \mathrm{O}_{8}$ in $50 \mathrm{mM}$ $\mathrm{Na}_{2} \mathrm{SiF}_{6} / \mathrm{NaHCO}_{3}$ buffer $(\mathrm{pH}=5.2)$ at different times $(0-20 \mathrm{~min})$ upon illumination with white light (white LED, $3.8 \mathrm{~mW} \cdot \mathrm{cm}^{-2}$, optical path of the cuvette $\left.=1 \mathrm{~mm}\right)$, in the presence of $1(400 \mu \mathrm{M}$, top left; $200 \mu \mathrm{M}$, top right; $100 \mu \mathrm{M}$, bottom left; $50 \mu \mathrm{M}$, bottom right). 

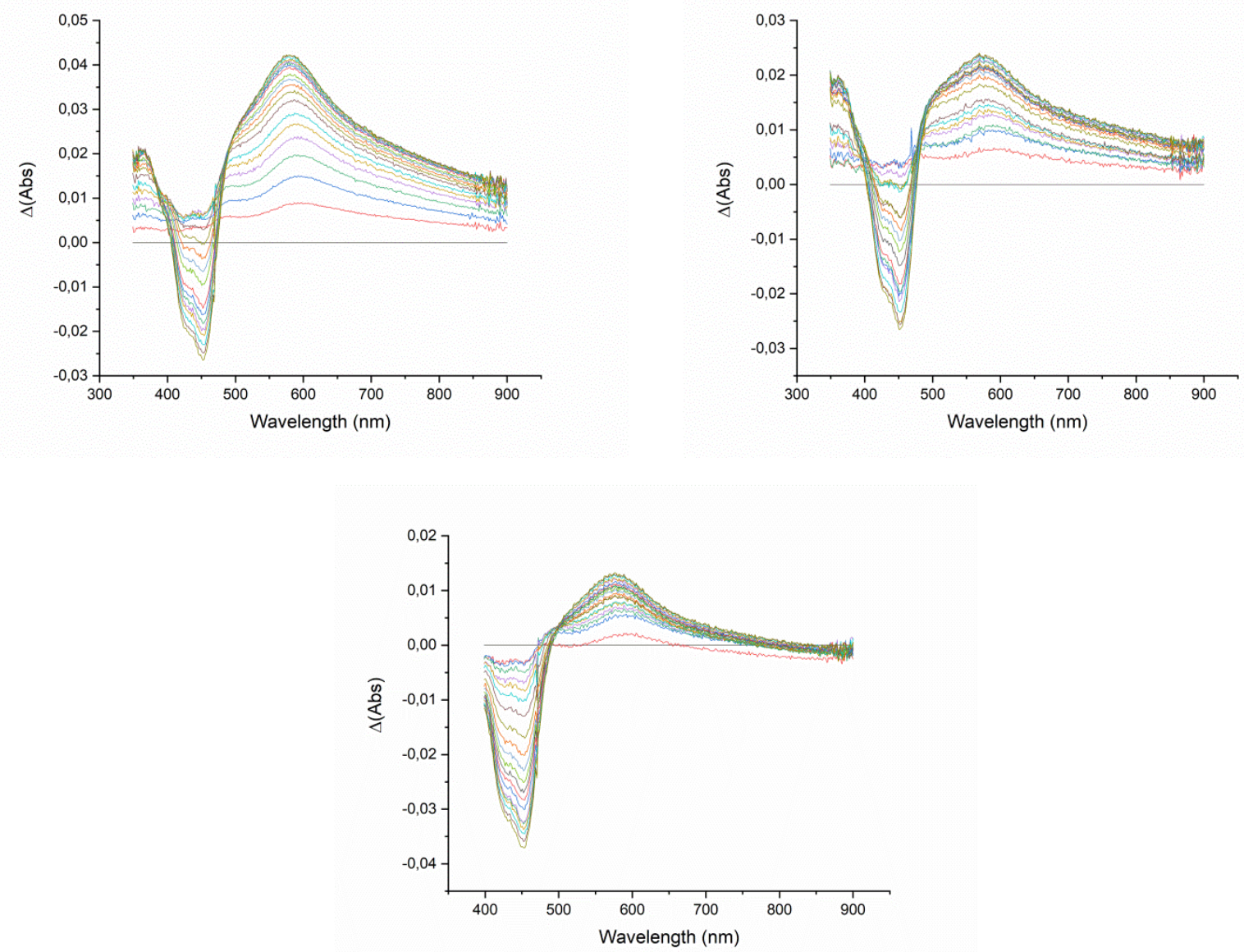

Figure S3. Differential Absorption spectra of solutions containing $1 \mathrm{mM} \mathrm{Ru(bpy)})_{3}{ }^{2+}, 5 \mathrm{mM}$ $\mathrm{Na}_{2} \mathrm{~S}_{2} \mathrm{O}_{8}$ in $50 \mathrm{mM} \mathrm{Na} \mathrm{SiF}_{6} / \mathrm{NaHCO}_{3}$ buffer $(\mathrm{pH}=5.2$ ) at different times $(0-20$ min) upon illumination with white light (white LED, $3.8 \mathrm{~mW} \cdot \mathrm{cm}^{-2}$, optical path of the cuvette $=1 \mathrm{~mm}$ ), in the presence of 1 ( $200 \mu \mathrm{M}$, top left; $100 \mu \mathrm{M}$, top right; $50 \mu \mathrm{M}$, bottom). 

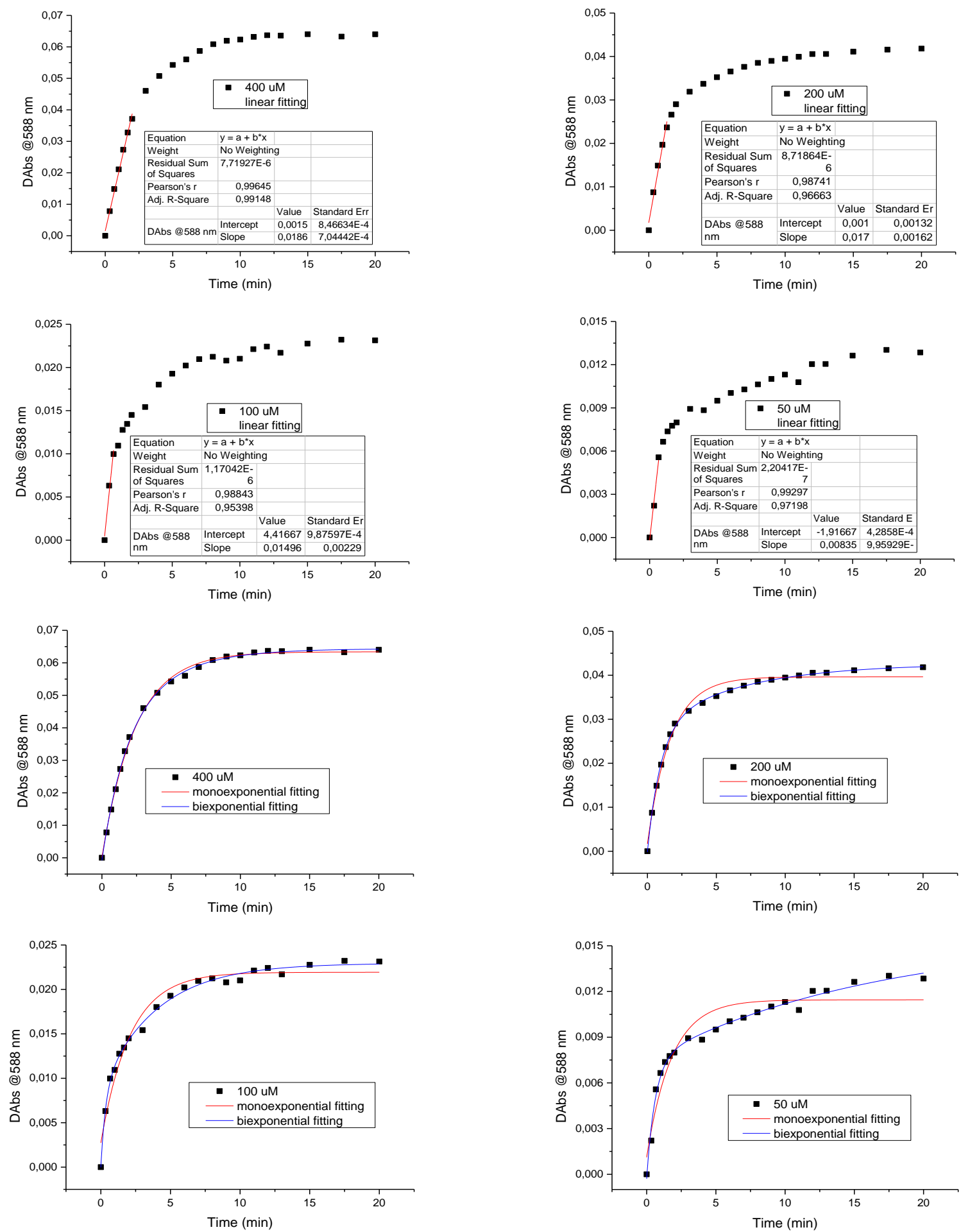

Figure S4. Top four panels: determination of initial rates of Ir-blue formation, from linear interpolation of initial Delta(Abs) at $588 \mathrm{~nm}$. Initial concentration of 1: $400 \mu \mathrm{M}$ (top left); $200 \mu \mathrm{M}$ (top right); $100 \mu \mathrm{M}$ (bottom left); $50 \mu \mathrm{M}$ (bottom right); same conditions as figure 1 in the main text. A molar extinction coefficient of $3200 \mathrm{M}^{-1} \mathrm{~cm}^{-1}$ at $588 \mathrm{~nm}$ can be estimated for Ir-blue from the plateauing absorbance values assuming quantitative conversion of $\mathbf{1}$ into Ir-blue. Bottom four panels: mono and biexponential fitting of the same traces. 

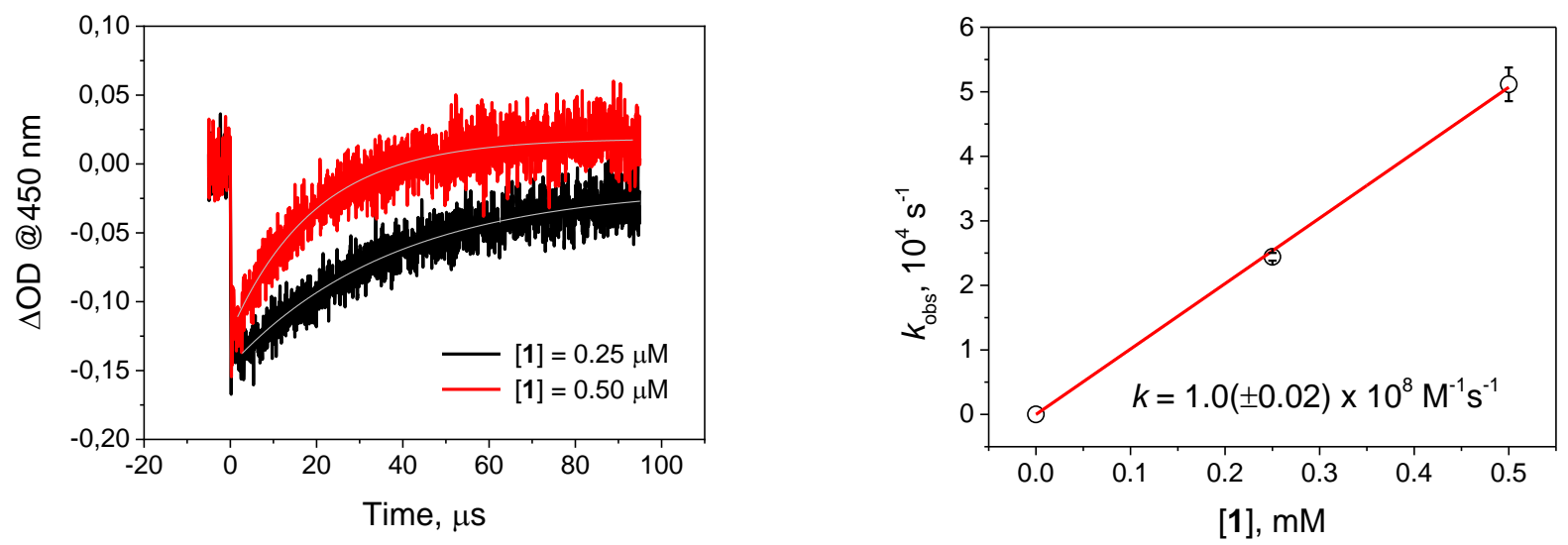

Figure S5. Left: laser flash photolysis experiments $\left(50 \mu \mathrm{M} \mathrm{Ru}(\mathrm{bpy})_{3}{ }^{2+}, 5 \mathrm{mM} \mathrm{Na} \mathrm{S}_{2} \mathrm{O}_{8}, 50 \mathrm{mM}\right.$ $\mathrm{Na}_{2} \mathrm{SiF}_{6} / \mathrm{NaHCO}_{3}$ buffer $\mathrm{pH} 5.2$, and $0.25-0.50 \mathrm{mM} \mathrm{1}$ ). The traces are fitted with a singleexponential function, that allow to determine a $k_{\mathrm{obs}}\left(\mathrm{s}^{-1}\right)$ for the process. Right: plot of $k_{\mathrm{obs}}\left(\mathrm{s}^{-1}\right) \mathrm{vs}$ [1], the slope of the linear fitting corresponds to the bimolecular rate constant for electron transfer). 


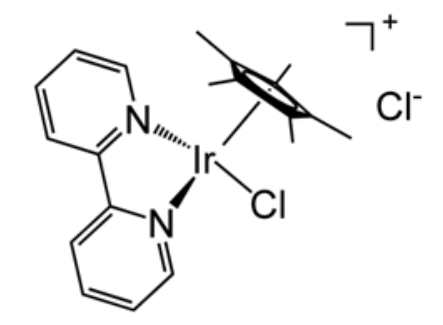

Ir(bpy)

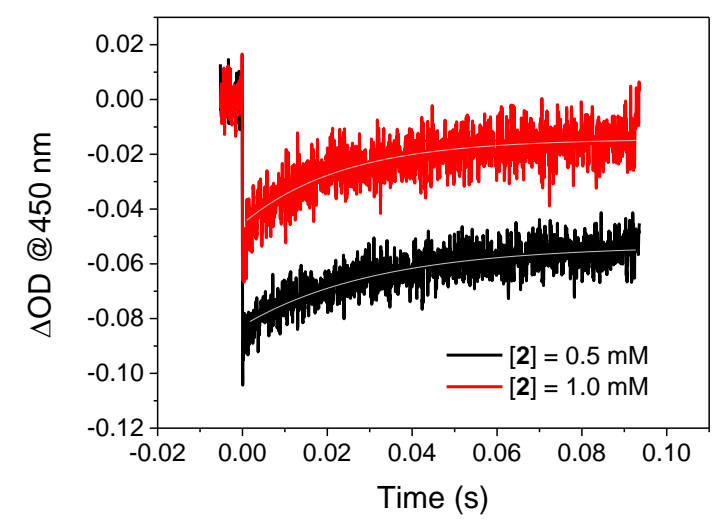

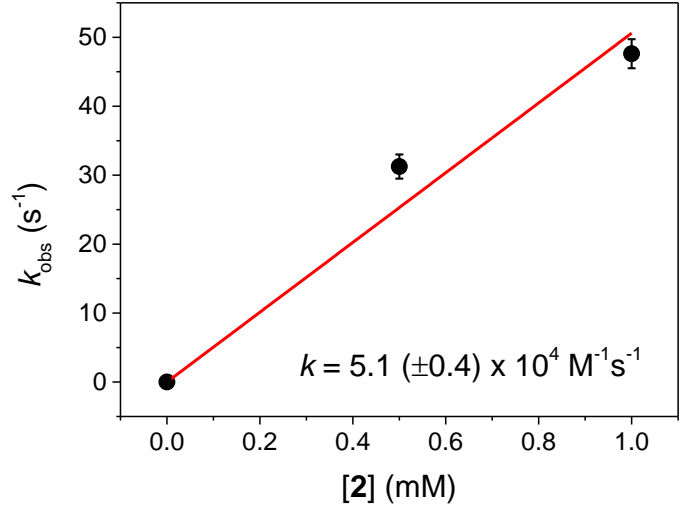

[2] (mM)

Figure S6. Left: laser flash photolysis experiments $\left(50 \mu \mathrm{M} \mathrm{Ru}(\mathrm{bpy})_{3}{ }^{2+}, 5 \mathrm{mM} \mathrm{Na} \mathrm{S}_{2} \mathrm{O}_{8}, 50 \mathrm{mM}\right.$ $\mathrm{Na}_{2} \mathrm{SiF}_{6} / \mathrm{NaHCO}_{3}$ buffer $\mathrm{pH}$ 5.2, and 0.25-0.50 mM [ $\operatorname{IrCl}($ bpy)Cp* $] \mathrm{Cl}, 2$, bpy=2,2'-bipyridine). The traces are fitted with a single-exponential function, that allows to determine a $k_{\mathrm{obs}}\left(\mathrm{s}^{-1}\right)$ for the process. Right: plot of $k_{\mathrm{obs}}\left(\mathrm{s}^{-1}\right)$ vs [2], the slope of the linear fitting corresponds to the bimolecular rate constant for electron transfer). 

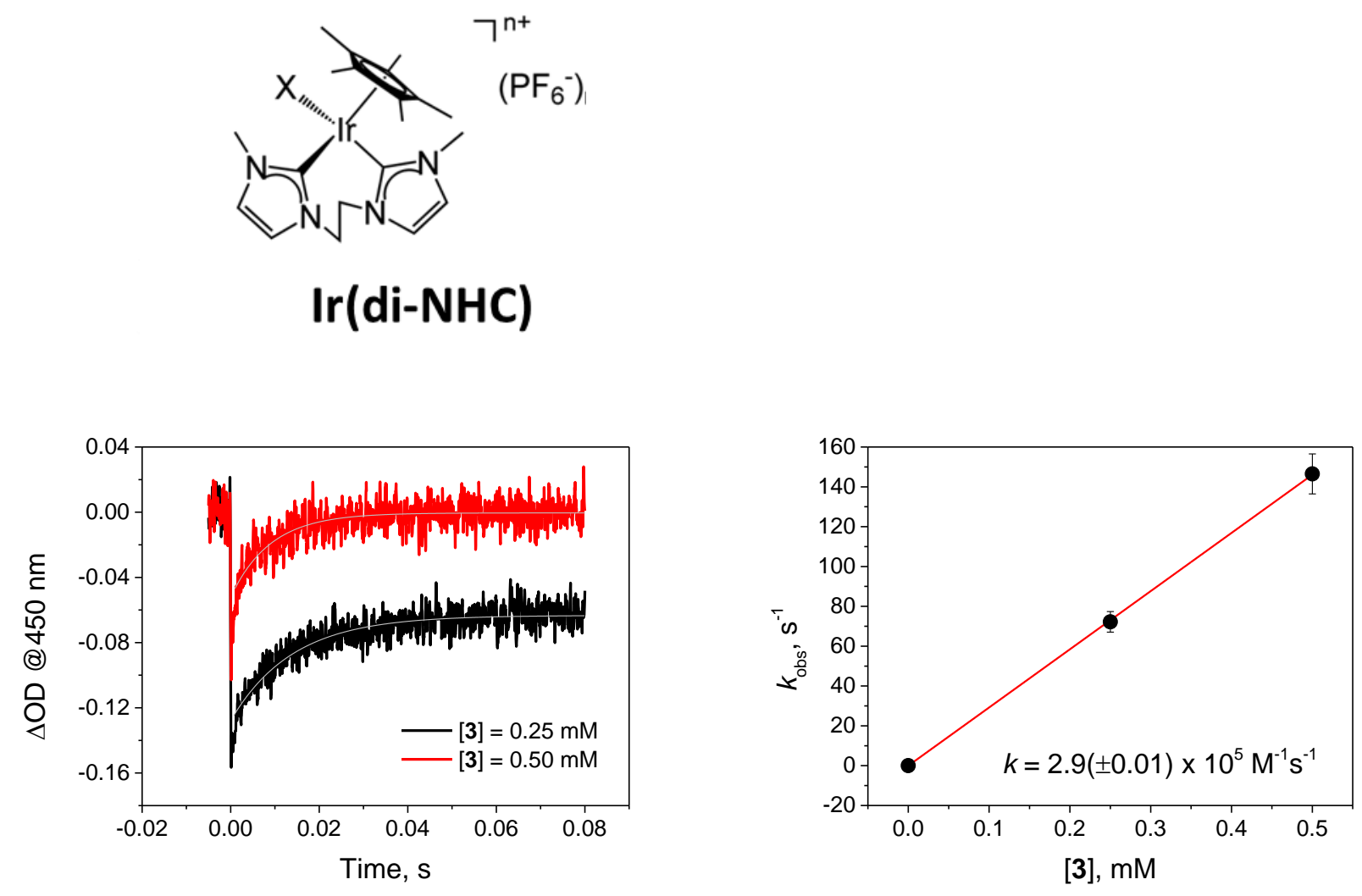

Figure S7. Left: laser flash photolysis experiments $\left(50 \mu \mathrm{M} \mathrm{Ru}(\mathrm{bpy})_{3}{ }^{2+}, 5 \mathrm{mM} \mathrm{Na} 2 \mathrm{~S}_{2} \mathrm{O}_{8}, 50 \mathrm{mM}\right.$ $\mathrm{Na}_{2} \mathrm{SiF}_{6} / \mathrm{NaHCO}_{3}$ buffer pH 5.2 with $10 \%$ acetonitrile, and $0.25-0.50 \mathrm{mM}[\mathrm{IrCl}(\mathrm{di}-\mathrm{NHC}) \mathrm{Cp} *] \mathrm{Cl}, \mathbf{3}$, di-NHC = 1,1-dimethyl-3,3-ethylenediimidazole-2,2-diylidene). The traces are fitted with a singleexponential function, that allows to determine a $k_{\mathrm{obs}}\left(\mathrm{s}^{-1}\right)$ for the process. Right: plot of $k_{\mathrm{obs}}\left(\mathrm{s}^{-1}\right) \mathrm{vs}$ [3], the slope of the linear fitting corresponds to the bimolecular rate constant for electron transfer). 

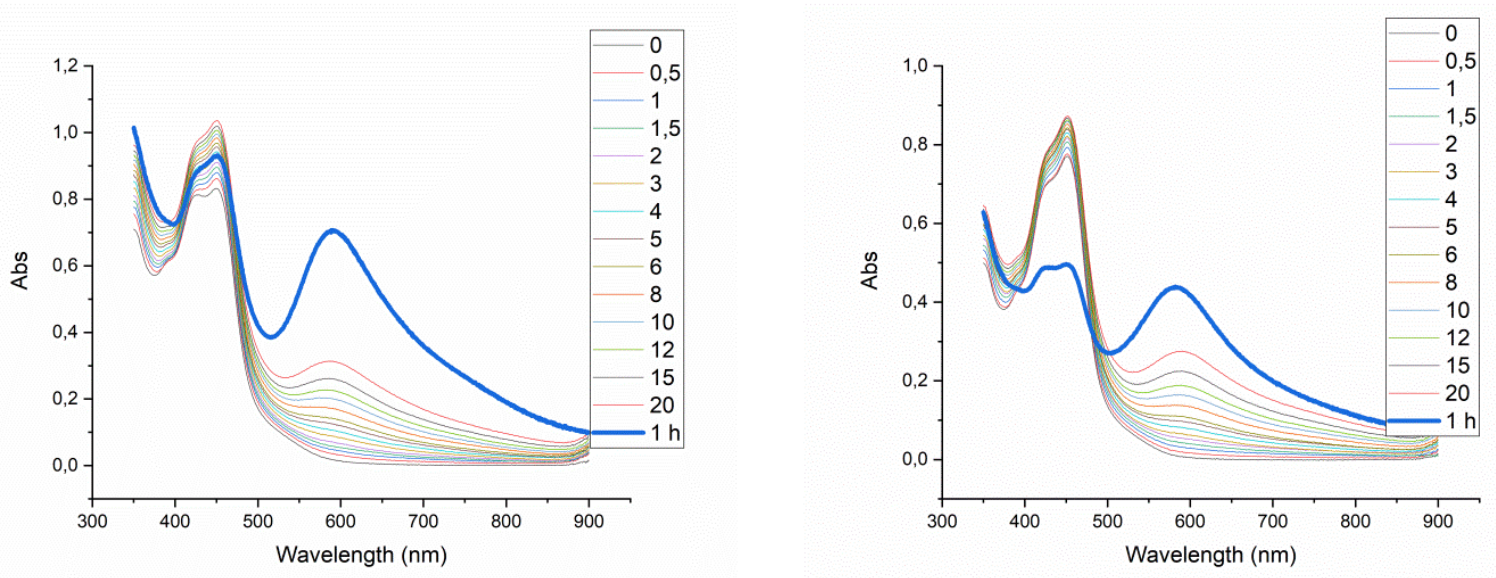

Figure S8. Absorption spectra of solutions containing $50 \mu \mathrm{M} \mathrm{Ru}(\mathrm{bpy})_{3}{ }^{2+}, 5 \mathrm{mM} \mathrm{Na}_{2} \mathrm{~S}_{2} \mathrm{O}_{8}$ in $50 \mathrm{mM}$ $\mathrm{Na}_{2} \mathrm{SiF}_{6} / \mathrm{NaHCO}_{3}$ buffer $(\mathrm{pH}=5.2)$ at different times $(0-1 \mathrm{~h})$ upon illumination with white light (white LED, $3.8 \mathrm{mWcm}^{-2}$, optical path of the cuvette $\left.=1 \mathrm{~mm}\right)$, in the presence of $1(500 \mu \mathrm{M}$, left; $250 \mu \mathrm{M}$, right). Plateau of the formation of the absorption centered at ca $600 \mathrm{~nm}$ is observed in both cases after $1 \mathrm{~h}$ irradiation, where parallel partial decomposition of $\mathrm{Ru}(\mathrm{bpy})_{3}{ }^{2+}$ is noticed by the bleach of the absorption at $450 \mathrm{~nm}$. 

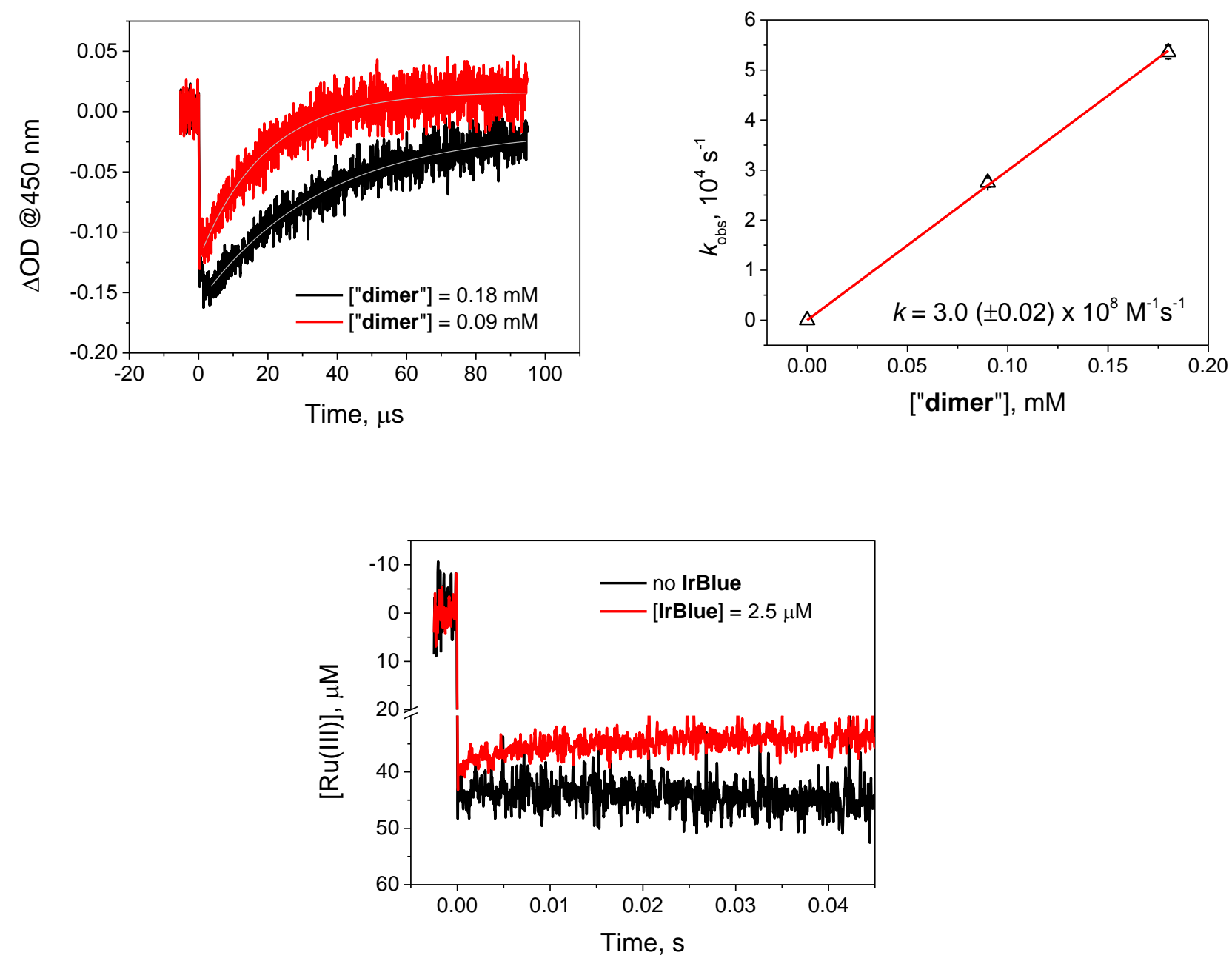

Figure S9. Top left: laser flash photolysis experiments $\left(50 \mu \mathrm{M} \mathrm{Ru}(\mathrm{bpy})_{3}{ }^{2+}, 5 \mathrm{mM} \mathrm{Na} 2 \mathrm{~S}_{2} \mathrm{O}_{8}, 50 \mathrm{mM}\right.$ $\mathrm{Na}_{2} \mathrm{SiF}_{6} / \mathrm{NaHCO}_{3}$ buffer $\mathrm{pH}$ 5.2, and 0.09-0.18 mM Ir-blue, generated upon treatment of 1 with 100 eq of $\mathrm{NaIO}_{4}$ in the same buffer). The traces are fitted with a single-exponential function, that allow to determine a $k_{\mathrm{obs}}\left(\mathrm{s}^{-1}\right)$ for the process. Top right: plot of $k_{\mathrm{obs}}\left(\mathrm{s}^{-1}\right)$ vs [Ir-blue], the slope of the linear fitting corresponds to the bimolecular rate constant for electron transfer). Bottom: laser flash photolysis experiments $\left(100 \mu \mathrm{M} \mathrm{Ru}(\text { bpy })_{3}{ }^{2+}, 5 \mathrm{mM} \mathrm{Na}_{2} \mathrm{~S}_{2} \mathrm{O}_{8}, 50 \mathrm{mM} \mathrm{Na} \mathrm{SiF}_{6} / \mathrm{NaHCO}_{3}\right.$ buffer $\mathrm{pH}$ 5.2, and 0-2.5 $\mu \mathrm{M}$ Ir-blue, higher laser power). 


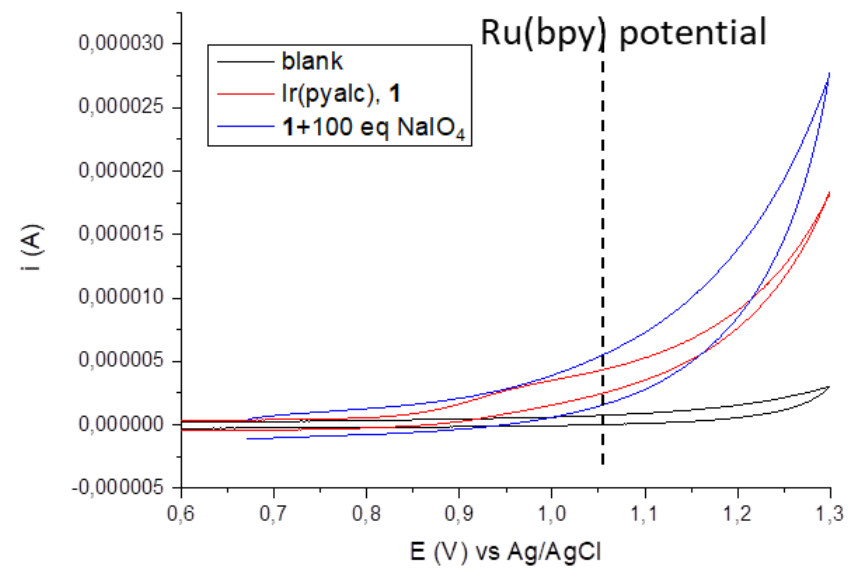

Figure S10. Cyclic voltammetry analysis of $\mathbf{1}$ before (red trace) and after (blue trace) activation with 100 eq. $\mathrm{NaIO}_{4}$. $0.5 \mathrm{mM} 1$ in $50 \mathrm{mM} \mathrm{NaHCO} 3 \mathrm{Na}_{2} \mathrm{SiF}_{6}$ buffer, pH 5.2. Working electrode: glassy carbon; counter electrode: platinum; reference electrode: $\mathrm{Ag} / \mathrm{AgCl}(3 \mathrm{M} \mathrm{KCl})$, scan rate 50 $\mathrm{mV} / \mathrm{sec}$.

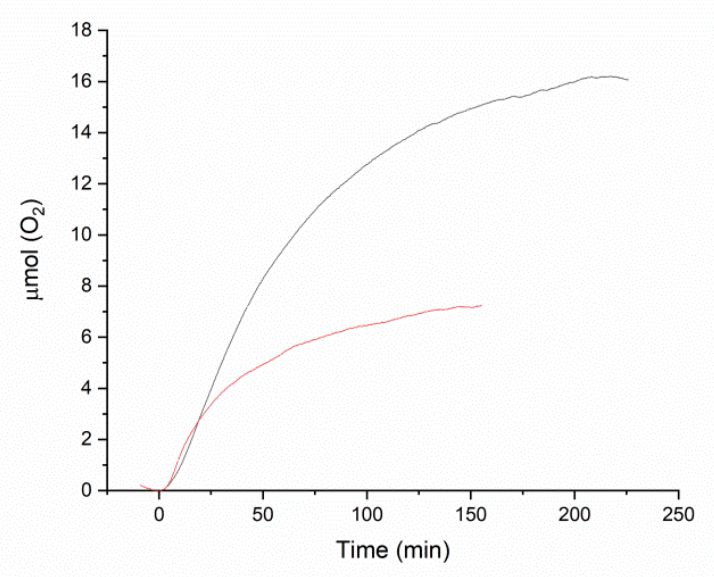

Figure S11. Oxygen evolution kinetics with precatalyst 1 with white light; reaction conditions: 15 $\mathrm{mL}$ of $50 \mathrm{mM} \mathrm{Na}_{2} \mathrm{SiF}_{6} / \mathrm{NaHCO}_{3}$ buffer, $\mathrm{pH} 5.2 ;\left[\mathrm{Ru}(\mathrm{bpy})_{3}{ }^{2+}\right]=1 \mathrm{mM} ;\left[\mathrm{Na}_{2} \mathrm{~S}_{2} \mathrm{O}_{8}\right]=5 \mathrm{mM} ;[1]=50$ $\mu \mathrm{M}$ (introduced from a freshly prepared $2.5 \mathrm{mM}$ solution in the same buffer). The red trace is obtained by recharging the first run with further $5 \mathrm{mM} \mathrm{Na}_{2} \mathrm{~S}_{2} \mathrm{O}_{8}$, and purging the solution with $\mathrm{N}_{2}$. 

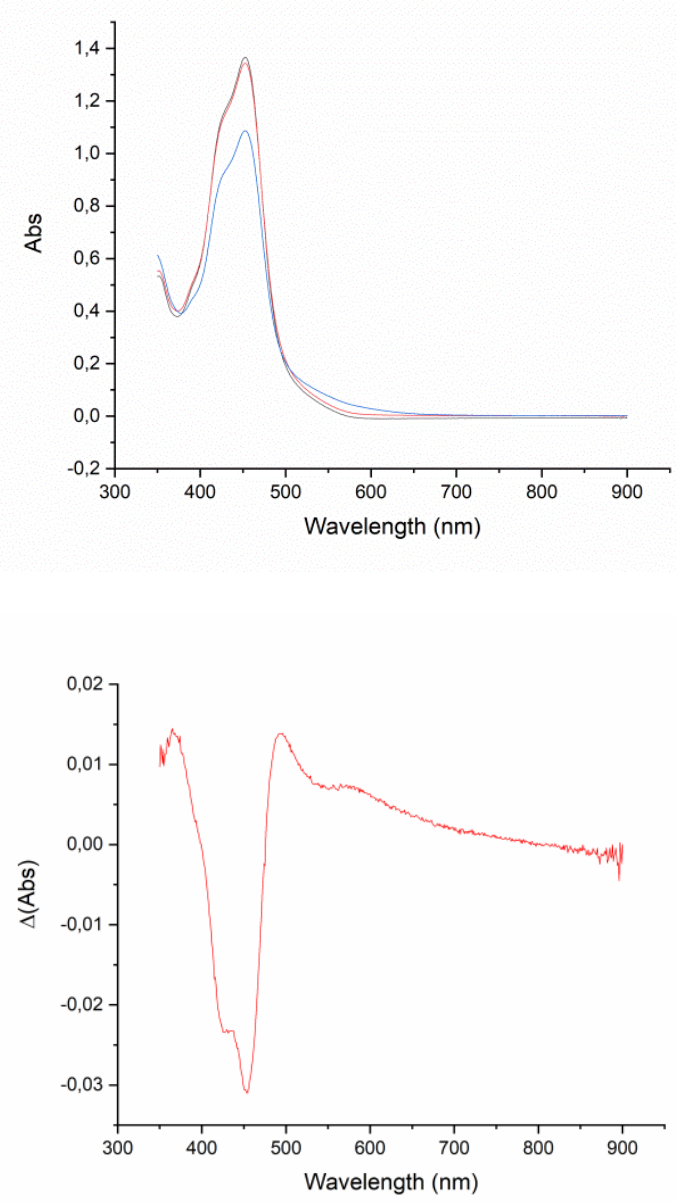

Figure S12. Top: absorption spectra of the photocatalytic reaction mixture before (black), after the first run (red), and after the second run involving persulfate recharge (blue). Bottom: differential absorption spectra of the solution used in the first photocatalytic $\mathrm{O}_{2}$ production cycle (obtained by subtraction of black spectra from red spectra in figure S12 top). Conditions: $50 \mu \mathrm{M} \mathrm{1,} 1 \mathrm{mM}$ $\mathrm{Ru}(\mathrm{bpy})_{3}{ }^{2+}, 5 \mathrm{mM} \mathrm{Na}_{2} \mathrm{~S}_{2} \mathrm{O}_{8}$ in $50 \mathrm{mM} \mathrm{Na} \mathrm{SiF}_{6} / \mathrm{NaHCO}_{3}$ buffer $(\mathrm{pH}=5.2)$ irradiated with white light (white LED, $3.8 \mathrm{~mW} \cdot \mathrm{cm}^{-2}$, optical path of the cuvette $=1 \mathrm{~mm}$ ). See entry 1 in table 1 in the main manuscript and figure $\mathrm{S} 11$ for the $\mathrm{O}_{2}$ traces. 

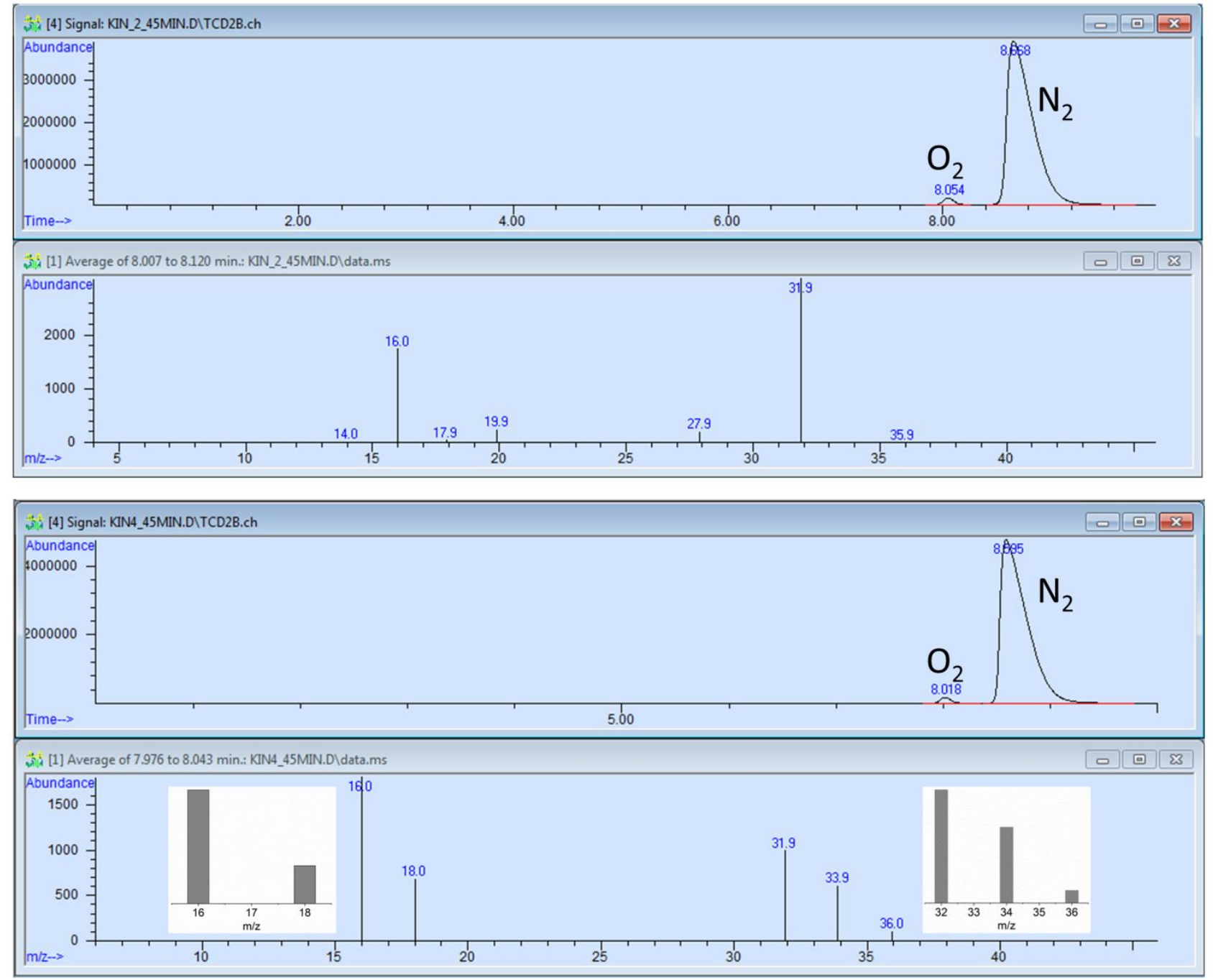

Figure S13. Gas chromatography coupled to mass spectrometry analysis of the headspace of the photocatalytic reaction. Reaction conditions: $2 \mathrm{~mL}$ of $50 \mathrm{mM} \mathrm{Na} 2 \mathrm{SiF}_{6} / \mathrm{NaHCO}_{3}$ buffer, pH 5.2; $\left[\mathrm{Ru}(\mathrm{bpy})_{3}{ }^{2+}\right]=1 \mathrm{mM} ;\left[\mathrm{Na}_{2} \mathrm{~S}_{2} \mathrm{O}_{8}\right]=5 \mathrm{mM} ;[1]=50 \mu \mathrm{M}$. Irradiation was performed with a white LED lamp positioned at $20 \mathrm{~cm}$ from the reactor $\left(3.8 \mathrm{~mW} / \mathrm{cm}^{2}\right)$. Top: experiment conducted in $\mathrm{H}_{2}{ }^{16} \mathrm{O}$; Bottom: experiment conducted in $25 \%{ }^{18} \mathrm{O}$ enriched water; the inset shows the calculated isotopic pattern for the $\mathrm{O}_{2}{ }^{+}(\mathrm{m} / \mathrm{z}$ values between $32-36)$ and $\mathrm{O}^{+}(\mathrm{m} / \mathrm{z}$ values between $16-18)$ ions . 


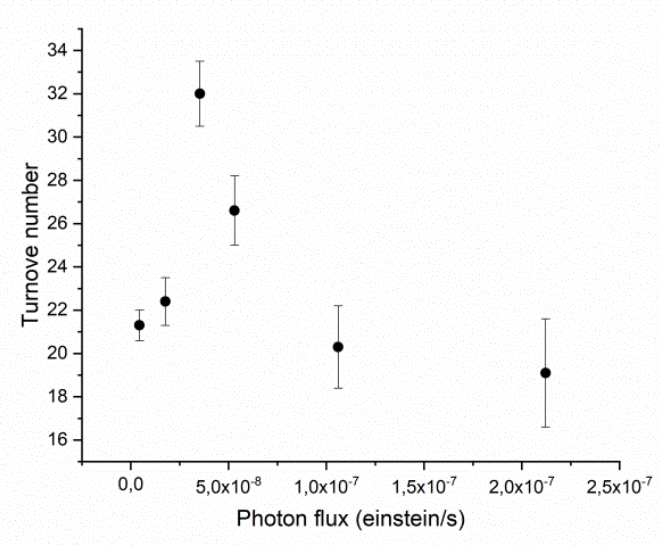

Figure S14. Turnover number for oxygen evolution (calculated per Ir center) versus photon flux (data in Table 1 in the main text). Reaction conditions: $15 \mathrm{~mL}$ of $50 \mathrm{mM} \mathrm{Na} \mathrm{SiF}_{6} / \mathrm{NaHCO}_{3}$ buffer, pH 5.2; $\left[\mathrm{Ru}(\text { bpy })_{3}{ }^{2+}\right]=1 \mathrm{mM} ;\left[\mathrm{Na}_{2} \mathrm{~S}_{2} \mathrm{O}_{8}\right]=5 \mathrm{mM} ;[1]=50 \mu \mathrm{M}$ (loaded from a $2.5 \mathrm{mM}$ solution prepared in the same buffer). Irradiation was performed with a series of six monochromatic LEDs emitting at $450 \mathrm{~nm}\left(4.42 \times 10^{-9}-2.12 \times 10^{-7}\right.$ einstein $\left.\cdot \mathrm{s}^{-1}\right)$. 
Table S1. Initial rates of Ir-blue formation and quantum yield estimation.

\begin{tabular}{|c|c|c|c|c|}
\hline$[1], \mu \mathrm{M}$ & $\begin{array}{l}\mathbf{R}_{\mathbf{R u}}=\text { Rate } \mathbf{R u}(\mathrm{III}) \\
\text { form. }{ }^{\text {[a] }}\end{array}$ & $\begin{array}{l}R_{0}=\text { Rate Ir blue } \\
\text { dimer form. }{ }^{[b]}\end{array}$ & $\mathbf{R}_{\mathbf{R u}} / \mathbf{R}_{\mathbf{0}}$ & $\phi_{\text {Ir-blue }}{ }^{[c]}$ \\
\hline 50 & $2.21 \times 10^{-5} \mathrm{M} \cdot \mathrm{s}^{-1}$ & $0.44 \times 10^{-6} \mathrm{M} \cdot \mathrm{s}^{-1}$ & 50.2 & 0.04 \\
\hline 100 & $2.21 \times 10^{-5} \mathrm{M} \cdot \mathrm{s}^{-1}$ & $0.78 \times 10^{-6} \mathrm{M} \cdot \mathrm{s}^{-1}$ & 28.3 & 0.07 \\
\hline 200 & $2.21 \times 10^{-5} \mathrm{M} \cdot \mathrm{s}^{-1}$ & $1.15 \times 10^{-6} \mathrm{M} \cdot \mathrm{s}^{-1}$ & 19 & 0.10 \\
\hline 400 & $2.21 \times 10^{-5} \mathrm{M} \cdot \mathrm{s}^{-1}$ & $1.0 \times 10^{-6} \mathrm{M} \cdot \mathrm{s}^{-1}$ & 22.1 & 0.09 \\
\hline
\end{tabular}

[a] The rate of $\mathrm{Ru}$ (III) formation is calculated from the fitting in Figure $\mathrm{S} 4$, with $[\mathrm{Ru}(\mathrm{II})]_{0}=1 \mathrm{mM}$;

[b] Concomitant to Ir-blue formation, water oxidation occurs; [c] Quantum yield for Ir-blue dimer formation $=$ mol of Ir-blue /absorbed photons $=\mathrm{R}_{0} / \mathrm{R}_{\mathrm{Ru}} \times \mathrm{QY} \mathrm{Ru}_{\mathrm{Ru}(I I) \text { formation }}\left(\mathrm{QY}_{\mathrm{Ru}(\text { III) formation }}=2\right)$. 
Table S2. Hole scavenging rate constants determined by flash photolysis for $\operatorname{Ir}(\mathrm{III})$ pre-catalysts.

(III) species

\section{References}

\footnotetext{
${ }^{1}$ Wong, Y.-L.; Yang, Q.; Zhou, Z.-Y.; Lee, H. K.; Mak, T. C. W.; Ng, D. K. P. Synthesis, structure and oxo-transfer properties of dioxotungsten(VI) complexes with pyridine-based NO- and NSbidentate ligands. New J. Chem. 2001, 25, 353.

2 Hintermair, U.; Hashmi, S. M.; Elimelech, M.; Crabtree, R. H. Particle Formation during Oxidation Catalysis with Cp* Iridium Complexes. J. Am. Chem. Soc. 2012, 134, 9785.
} 